\title{
56. EXPERIMENTAL PETROLOGY OF BASEMENT BASALTIC ROCKS FROM SITES 794 AND 797, JAPAN SEA ${ }^{1}$
}

\author{
Shigeru Yamashita ${ }^{2}$ and Toshitsugu Fujii ${ }^{2}$
}

\begin{abstract}
The relatively fresh basement basaltic rocks cored at Sites 794 and 797 during ODP Legs 127 and 128 show compositional variations suggesting the following: (1) the aphyric rocks might be differentiated from compositional equivalents of the aphyric sample with the lowest $\mathrm{FeO} * \mathrm{MgO}$ (Sample 127-797C-12R-4, 35-37 cm); and (2) the plagioclase-phyric rocks (i.e., another constituent of the basement basaltic rocks from the sites) may be derivatives from the same parents; in this case, however, crystallized plagioclase was not effectively removed. Melting experiments were conducted for Sample 127-797C-12R-4, 35-37 $\mathrm{cm}$, and the differentiation processes for the basement basaltic rocks were assessed. The high-pressure melting-phase relation can not account for the compositional variation of the aphyric rocks, suggesting that the variation was developed at relatively low pressure where olivine and plagioclase fractionation was followed by $\mathrm{Ca}$-rich clinopyroxene fractionation. The density of Sample $127-797 \mathrm{C}-12 \mathrm{R}-4,35-37 \mathrm{~cm}$, is comparable to that of plagioclase at some depth, but at still relatively low pressure, making it possible that the liquidus plagioclase was retained in the successive liquids to produce the plagioclase-phyric rocks. According to backtrack calculation assuming the olivine maximum fractionation, Sample $127-797 \mathrm{C}-12 \mathrm{R}-4,35-37 \mathrm{~cm}$, was differentiated from primary picritic high-Al basalt magma. The estimated primary magma composition was experimentally proved to coexist with harzburgite mantle at about $14 \mathrm{kbar}$, suggesting relatively shallow production (approximately $40-50 \mathrm{~km}$ below surface) of the rifting-related primary magma.
\end{abstract}

\section{INTRODUCTION}

The Japan Sea is an inactive backarc basin situated at the active margin of the eastern Asian continent (Fig. 1). It is generally understood that the basinal area of the Japan Sea was created by regional rifting at the active continental margin, i.e., regional stretching and probable detachment of the rigid continental lithosphere, during the early to middle Miocene (e.g., Otofuji et al., 1985; Celeya and McCabe, 1987; Tamaki, 1988). From the analogous formation of other backarc basins (e.g., Hawkins and Melchoir, 1985), it is believed that regional and intense basalt magmatism was associated with the rifting that created the basinal area of the Japan Sea. The nature of the magmatism, however, has been obscured by the thick accumulation of post-Miocene sediments in the basin which had precluded sampling basement igneous rocks.

Basement cores of the basinal area were first attained during Ocean Drilling Program Legs 127 and 128 (Tamaki, Pisciotto, Allan, et al., 1990; Ingle, Suyehiro, von Breymann, et al., 1990). In the Yamato Basin, which occupies the southern part of the basinal area, the coring successfully recovered relatively fresh basement basaltic rocks at Sites 794 and 797, which are located at the western margin and northeastern center of the basin, respectively (Fig. 1). We present here the results of melting experiments on some starting compositions in synthesis with petrographic features and major-element chemistry of the basement basaltic rocks cored at Sites 794 and 797 to characterize the rifting-related magmatism in the basin.

\section{BASEMENT BASALTIC ROCKS}

\section{Occurrence}

The cored sequence of basement is composed principally of interbedded basaltic bodies and lower to middle Miocene marine sediments at Sites 794 and 797 (Fig. 2) (Tamaki, Pisciotto, Allan, et al., 1990; Ingle, Suyehiro, von Breymann, et al., 1990). The basaltic bodies occur predominantly as sills rather than subaqueous lava flows

\footnotetext{
${ }^{1}$ Tamaki, K., Suyehiro, K., Allan, J., McWilliams, M., et al., 1992. Proc. ODP, Sci. Results, 127/128, Pt. 2: College Station, TX (Ocean Drilling Program).

${ }^{2}$ Earthquake Research Institute, University of Tokyo, Yayoi 1-1-1, Tokyo 113, Japan.
}

(Tamaki, Pisciotto, Allan, et al., 1990). The cored basement composition confirms the prediction made by Tokuyama et al. (1987) and Hirata et al. (1989) based on the velocity structure. The velocity structure of the basement is similar throughout the basin, suggesting that this kind of basement underlies all of the Yamato basin (Tamaki, Pisciotto, Allan, et al., 1990).

The sills were interpreted to have intruded into the host marine sediments before significant lithification of the sediments (Tamaki, Pisciotto, Allan, et al., 1990), suggesting that their emplacement was nearly synchronized with deposition of the sediments. This timing of emplacement is consistent with their ${ }^{39} \mathrm{Ar} /{ }^{40} \mathrm{Ar}$ radiometric ages of about $20 \mathrm{Ma}$ (Kaneoka et al., this volume). Depositional environments of the intercalated sediments change from lower bathyal to upper bathyal with increasing depth at both drill sites (Tamaki, Pisciotto, Allan, et al., 1990; Tada, 1990), suggesting that the basement basaltic bodies were created at the same time as regional submergence, which was likely to occur during rifting of the area.

\section{Petrography}

All the basement basaltic rocks from Sites 794 and 797 show microscopic evidence of some extensive alteration (Tamaki, Pisciotto, Allan, et al., 1990; Ingle, Suyehiro, von Breymann, et al., 1990). Some rocks, particularly constituents of the chilled marginal part of sills, have been highly altered to form considerable amounts of secondary minerals (chlorite, smectite, saponite, K-rich mica, pyrite, and carbonate) while constituents of the internal part of sills are sporadically free from such alteration. The amounts of secondary minerals vary from $>40$ vol. \% (in approximate mode) in highly altered rocks to almost null in slightly altered rocks (Tamaki, Pisciotto, Allan, et al., 1990; Ingle, Suyehiro, von Breymann, et al., 1990). In the former, mafic minerals and mesostasis are totally replaced by secondary minerals. Fractures and veins filled by secondary minerals are commonly developed in the rocks.

As for the primary petrographic features, the basement basaltic rocks from Sites 794 and 797 are rather uniform except for modal amounts of plagioclase phenocrysts. These are roughly divided into the following three groups: (1) aphyric basalt and dolerite, (2) sparsely to moderately plagioclase-phyric basalt and dolerite, and (3) highly plagioclase-phyric basalt and dolerite. Each group contains 


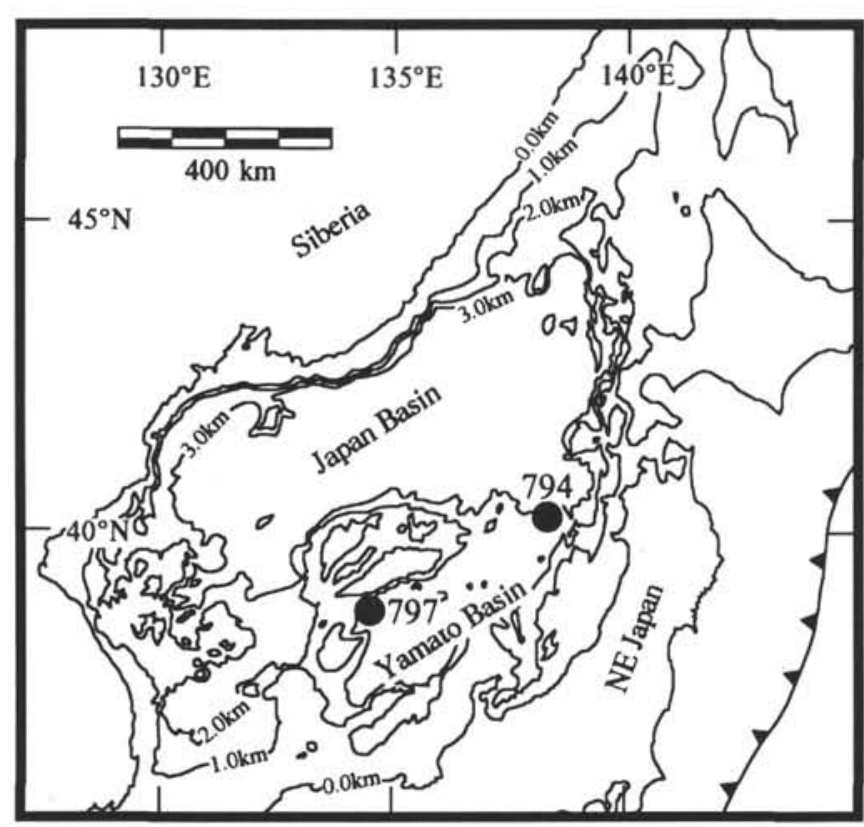

Figure 1. Bathymetric features of the Japan Sea. Solid circles indicate Sites 794 and 797 cored during Legs 127 and 128.

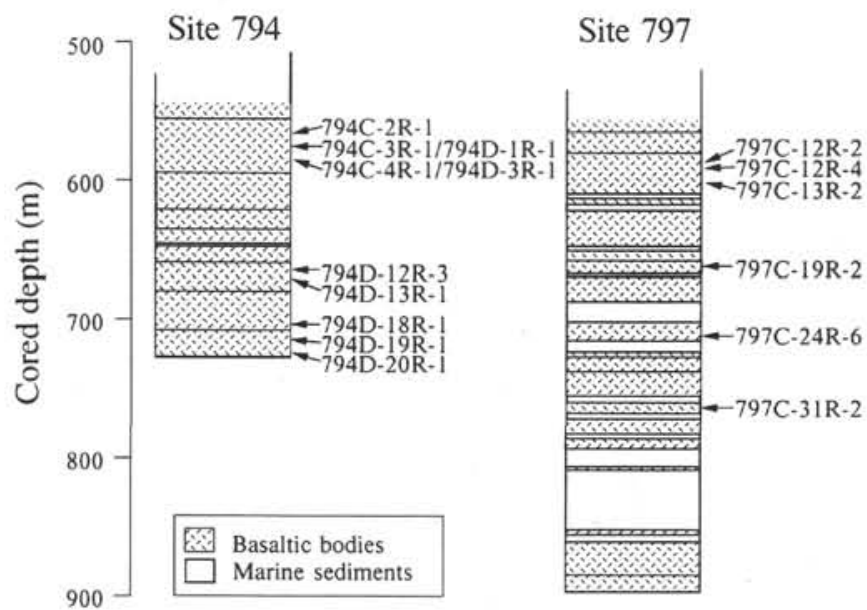

Figure 2. Schematic lithostratigraphy of the basement cored at Sites 794 and 797. Arrows denote approximate horizons where the rocks studied here (Table 1) were sampled.

euhedral to subhedral plagioclase phenocrysts of $<1$ vol. $\%, 1$ to 5 vol.\%, and $>5 \mathrm{vol} . \%$, respectively. Euhedral to subhedral olivine phenocrysts are also sporadically present $(<1$ vol.\%). Reddish-brown colored $\mathrm{Cr}$-spinel occurs sparsely as inclusions in plagioclase and olivine phenocrysts. Phenocryst size ranges from 1 to $10 \mathrm{~mm}$ in diameter. The groundmass consists of plagioclase, augite, olivine, Fe-Ti oxide, and subordinate amounts of mesostasis and shows a variety of textures and grain sizes depending on its occurrence. It shows intersertal texture with constituent minerals less than $0.1 \mathrm{~mm}$ (i.e., basalt) in the marginal part of sills. In the internal part of sills, nearly holocrystalline ophitic, subophitic, and intergranular textures are commonly developed, and the constituent minerals are up to $3 \mathrm{~mm}$ in maximum (i.e., dolerite). In the dolerites, the coarse-grained nature of the groundmass can make it difficult to distinguish the phenocrysts from the groundmass minerals by grain size. In such rocks, the identification of phenocrysts was made according to the shape of crystals, from euhedral to subhedral.

\section{Chemistry}

Shipboard whole-rock X-ray fluorescence (XRF) analyses of the basement basaltic rocks from Sites 794 and 797 are reported elsewhere together with the measurement of whole-rock loss on ignition (LOI) (Tamaki, Pisciotto, Allan, et al., 1990; Ingle, Suyehiro, von Breymann, et al., 1990). In general, seafloor alteration remarkably affects the chemical composition of subaqueously emplaced igneous rocks. Because the basement basaltic rocks underwent some extensive alteration, any interpretation based on their chemistry should be made very carefully.

The shipboard whole-rock LOI measurement shows a wide range, from <1 to 8 wt.\% (Tamaki, Pisciotto, Allan, et al., 1990; Ingle, Suyehiro, von Breymann, et al., 1990). Chemical change in the rocks due to alteration may be well expressed by variation in the $\mathrm{CaO}$ and $\mathrm{K}_{2} \mathrm{O}$ contents and $\mathrm{FeO} * / \mathrm{MgO}$ ratio as a function of the $\mathrm{LOI}$ value (Fig. 3) because of the following reasons: (1) LOI value should be a good indicator of extent of the seafloor alteration with the development of secondary clay minerals; and (2) $\mathrm{K}, \mathrm{Ca}$, and $\mathrm{Mg}$ belong to the most mobile elements during seafloor alteration of basaltic rock (e.g., Menzies and Seyfried, 1979; Seyfried and Mottl, 1982). In Figure 3, the basement basaltic rocks with higher LOI values show general enrichment in $\mathrm{K}_{2} \mathrm{O}$ and depletion in $\mathrm{CaO}$, and are displaced toward lower $\mathrm{FeO} * / \mathrm{MgO}$ side relative to those with lower $\mathrm{LOI}$ values. Because the correlations are recognized even among rocks taken from different positions within a single intrusive or extrusive unit (Fig. 3), the variations are due to alteration rather than to magmatic processes.
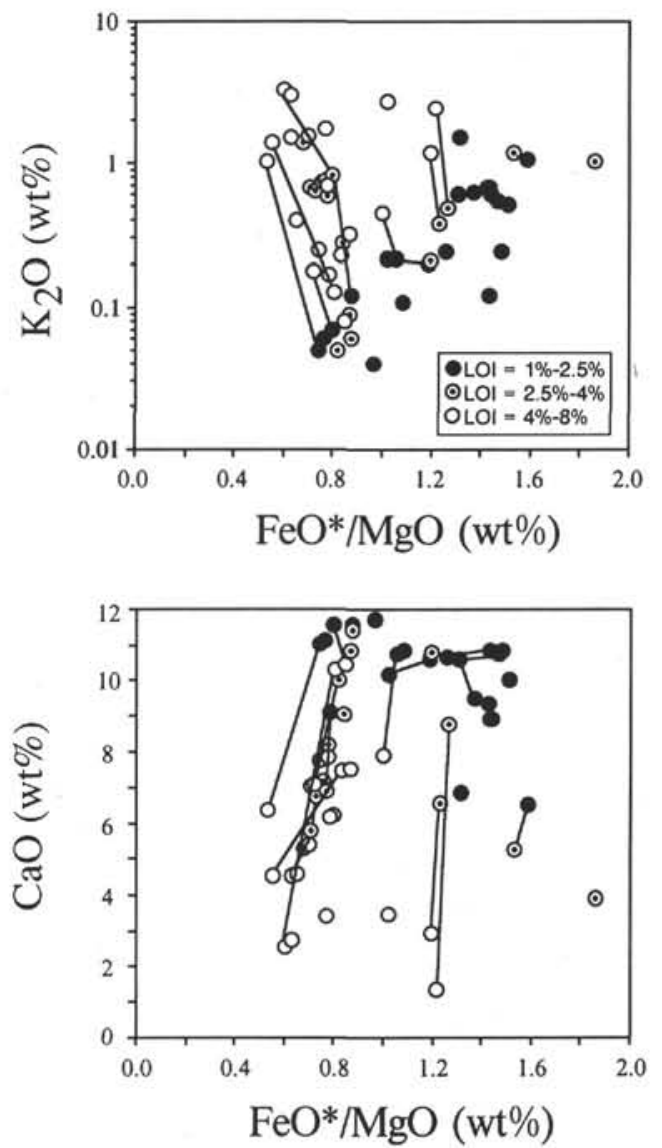

Figure 3. $\mathrm{CaO}, \mathrm{K}_{2} \mathrm{O}$, and $\mathrm{FeO} * / \mathrm{MgO}$ variations in the basement basaltic rocks, including highly altered ones, from Sites 794 and 797 as a function of LOI. Analyses of rocks taken from a single intrusive or effusive unit are connected by tie-lines. All the analyses are from Tamaki, Pisciotto, Allan, et al. (1990) and Ingle, Suyehiro, von Breymann, et al. (1990). 
All the relatively fresh rocks have LOI values $<2.5 \mathrm{wt}$.\% (Tamaki, Pisciotto, Allan, et al., 1990; Ingle, Suyehiro, von Breymann, et al., 1990). Note that, in Figure 3, the rocks with LOI values $<2.5 \mathrm{wt} . \%$ show limited variations with small change in $\mathrm{FeO} * / \mathrm{MgO}$ whereas the rocks with higher LOI values exhibit larger and scattered variations even with small change in $\mathrm{FeO}^{*} / \mathrm{MgO}$. In this study, we consider the relatively fresh rocks to retain the original magmatic compositions. All the analyses on the microscopically highly altered rocks are discarded though some of them have LOI values $<2.5 \mathrm{wt}$.\%. According to the present criteria, we performed several additional wholerock XRF analyses on the relatively fresh rocks at the Earthquake Research Institute, University of Tokyo, and utilize them too in the following interpretation. The details of analyses are given in Aramaki (1987) and essentially same as in Tamaki, Pisciotto, Allan, et al. (1990) and in Ingle, Suyehiro, von Breymann, et al. (1990).

The selected major element compositions of the basement basaltic rocks from Sites 794 and 797 show a general olivine tholeiitic affinity and are characterized by relatively high $\mathrm{Al}_{2} \mathrm{O}_{3}$ contents (15 to 21 wt.\%) (Table 1 and Figs. 4 and 5), classifying the rocks into the "high-Al basalt suite" defined by Kuno (1960). The basement basaltic rocks from Sites 794 and 797 exhibit Nd and Sr isotope- and incompatible trace element-signatures ranging from an N-type MORBs-like depleted one to a less depleted one, depending on the sampled site and horizon (Nohda et al., this volume; Tamaki, Pisciotto, Allan, et al., 1990; Ingle, Suyehiro, von Breymann, et al., 1990). This may suggest that parental magmas of the basement basaltic rocks had various isotope and incompatible trace element compositions. In terms of major element composition, however, this characteristics is obscured as described below. The aphyric ones among the selected basement basaltic rocks define rather single compositional trend in which the amount of the normative quartz component increases with increasing $\mathrm{FeO} * / \mathrm{MgO}$ (Fig. 4). This is also pronounced in major element oxides vs. $\mathrm{FeO} * / \mathrm{MgO}$ variations, particularly in $\mathrm{Al}_{2} \mathrm{O}_{3}$ vs. $\mathrm{FeO} * / \mathrm{MgO}$ variation (Fig. 5). These compositional features may suggest that, in terms of major element composition, the aphyric rocks were differentiated from parents equivalent to the aphyric rock with the lowest $\mathrm{FeO} * / \mathrm{MgO}$ (Sample 127-797C-12R-4, 35-37 cm; Table 1) although the parents might vary in terms of isotope and incompatible trace-element compositions. About compositional features of the plagioclase-phyric rocks, the following facts are noted (Fig. 5): (1)

Table 1. Whole-rock major element and nickel chemistry of the relatively fresh basement basaltic rocks from Sites 794 and 797.

\begin{tabular}{|c|c|c|c|c|c|c|c|c|c|c|c|}
\hline $\begin{array}{l}\text { Hole } \\
\text { Core-section, } \\
\text { interval }(\mathrm{cm})\end{array}$ & $\begin{array}{c}794 \mathrm{D} \\
12 \mathrm{R}-3,36\end{array}$ & $\begin{array}{c}794 \mathrm{D} \\
13 \mathrm{R}-1,81\end{array}$ & $\begin{array}{c}794 \mathrm{D} \\
18 \mathrm{R}-1,144\end{array}$ & $\begin{array}{c}794 \mathrm{D} \\
19 \mathrm{R}-1,11\end{array}$ & $\begin{array}{c}794 \mathrm{D} \\
20 \mathrm{R}-1,20\end{array}$ & $\begin{array}{c}797 \mathrm{C} \\
12 \mathrm{R}-2,81\end{array}$ & $\begin{array}{c}797 \mathrm{C} \\
12 \mathrm{R}-4,35\end{array}$ & $\begin{array}{c}797 \mathrm{C} \\
13 \mathrm{R}-2,70\end{array}$ & $\begin{array}{c}797 \mathrm{C} \\
31 \mathrm{R}-2,36\end{array}$ & $\begin{array}{c}797 \mathrm{C} \\
19 \mathrm{R}-2,42\end{array}$ & $\begin{array}{c}797 \mathrm{C} \\
24 \mathrm{R}-6,38\end{array}$ \\
\hline Analytical ID & $128 \mathrm{SB}$ & $128 \mathrm{SB}$ & $128 \mathrm{SB}$ & $128 \mathrm{SB}$ & $128 \mathrm{SB}$ & $127 \mathrm{SB}$ & $127 \mathrm{SB}$ & $127 \mathrm{SB}$ & $127 \mathrm{SB}$ & $127 \mathrm{SB}$ & $127 \mathrm{SB}$ \\
\hline Petrographic ID & A & A & A & A & A & A & A & A & A & PM & PM \\
\hline $\mathrm{SiO}_{2}$ & 48.87 & 48.64 & 49.37 & 48.42 & 47.73 & 47.33 & 47.48 & 48.67 & 50.24 & 49.14 & 47.98 \\
\hline $\mathrm{TiO}_{2}^{2}$ & 1.64 & 1.51 & 1.67 & 1.51 & 1.48 & 0.95 & 0.94 & 0.98 & 1.65 & 0.88 & 0.92 \\
\hline $\mathrm{Al}_{2} \mathrm{O}_{3}$ & 15.80 & 15.04 & 17.80 & 17.30 & 16.65 & 17.61 & 17.70 & 18.26 & 14.91 & 17.97 & 17.40 \\
\hline $\mathrm{FeO}^{*}$ & 10.66 & 10.40 & 7.81 & 9.48 & 9.58 & 7.46 & 7.37 & 7.24 & 9.25 & 6.47 & 7.67 \\
\hline $\mathrm{MnO}$ & 0.18 & 0.18 & 0.27 & 0.20 & 0.21 & 0.17 & 0.16 & 0.31 & 0.19 & 0.28 & 0.18 \\
\hline $\mathrm{MgO}$ & 7.43 & 8.26 & 7.39 & 7.99 & 9.36 & 9.76 & 9.91 & 7.48 & 6.13 & 8.12 & 8.75 \\
\hline $\mathrm{CaO}$ & 10.86 & 10.63 & 10.76 & 10.61 & 10.18 & 11.13 & 11.05 & 11.70 & 10.04 & 11.57 & 11.59 \\
\hline $\mathrm{Na}_{2} \mathrm{O}$ & 2.99 & 2.83 & 3.02 & 2.91 & 2.82 & 3.15 & 3.03 & 3.28 & 3.55 & 3.09 & 2.80 \\
\hline $\mathrm{K}_{2} \mathrm{O}$ & 0.12 & 0.24 & 0.22 & 0.20 & 0.22 & 0.06 & 0.05 & 0.04 & 0.52 & 0.07 & 0.12 \\
\hline $\mathrm{P}_{2} \mathrm{O}_{5}$ & 0.13 & 0.16 & 0.19 & 0.17 & 0.17 & 0.11 & 0.12 & 0.10 & 0.24 & 0.08 & 0.10 \\
\hline Total & 98.68 & 97.89 & 98.50 & 98.79 & 98.40 & 97.73 & 97.81 & 98.06 & 97.72 & 97.63 & 98.12 \\
\hline LOI & 0.9 & 0.76 & 2.26 & 2.44 & 2.18 & 1.94 & 1.98 & 2.33 & 1.64 & 2.4 & 2.12 \\
\hline $\mathrm{Ni}(\mathrm{ppm})$ & 82 & 129 & 124 & 137 & 124 & 163 & 165 & 145 & 36 & 101 & 94 \\
\hline $\mathrm{FeO} * / \mathrm{MgO}$ & 1.43 & 1.26 & 1.06 & 1.19 & 1.02 & 0.76 & 0.74 & 0.97 & 1.51 & 0.80 & 0.88 \\
\hline Hole & $794 \mathrm{C}$ & $794 \mathrm{C}$ & $794 C$ & 794D & $794 \mathrm{D}$ & $794 C$ & 794D & 794D & 794D & $797 \mathrm{C}$ & \\
\hline $\begin{array}{l}\text { Core-section, } \\
\text { interval }(\mathrm{cm})\end{array}$ & 2R-1. 77 & $3 \mathrm{R}-1,22$ & $4 \mathrm{R}-1,42$ & $1 \mathrm{R}-1,96$ & $3 R-3,89$ & $3 \mathrm{R}-1,115$ & $12 \mathrm{R}-3,124$ & $13 \mathrm{R}-1,122$ & $20 \mathrm{R}-1,1$ & $31 \mathrm{R}-2,46$ & \\
\hline Analytical ID & $127 \mathrm{SB}$ & $127 \mathrm{SB}$ & $127 \mathrm{SB}$ & $128 \mathrm{SB}$ & $128 \mathrm{SB}$ & ERI & ERI & ERI & ERI & ERI & \\
\hline Petrographic ID & PH & PH & $\mathrm{PH}$ & PH & PH & PH & A & A & A & A & \\
\hline $\mathrm{SiO}_{2}$ & 50.49 & 50.57 & 51.21 & 50.64 & 50.04 & 50.05 & 48.79 & 48.79 & 48.49 & 50.87 & \\
\hline $\mathrm{TiO}_{2}$ & 1.24 & 1.14 & 1.09 & 1.31 & 1.27 & 1.28 & 1.65 & 1.54 & 1.48 & 1.78 & \\
\hline $\mathrm{Al}_{2} \mathrm{O}_{3}$ & 19.28 & 21.18 & 20.23 & 19.56 & 18.11 & 19.18 & 15.74 & 16.07 & 16.63 & 14.72 & \\
\hline $\mathrm{FeO}^{*}$ & 8.14 & 8.02 & 7.81 & 9.22 & 9.01 & 7.80 & 10.51 & 10.15 & 9.34 & 9.83 & \\
\hline $\mathrm{MnO}$ & 0.12 & 0.12 & 0.13 & 0.13 & 0.12 & 0.12 & 0.15 & 0.16 & 0.16 & 0.16 & \\
\hline $\mathrm{MgO}$ & 5.69 & 5.45 & 5.98 & 6.40 & 6.57 & 5.18 & 7.50 & 8.14 & 7.60 & 6.20 & \\
\hline $\mathrm{CaO}$ & 8.92 & 10.75 & 10.60 & 8.91 & 9.50 & 10.51 & 10.61 & 10.68 & 10.71 & 10.04 & \\
\hline $\mathrm{Na}_{2} \mathrm{O}$ & 3.71 & 3.33 & 3.39 & 3.46 & 3.25 & 3.08 & 3.03 & 2.94 & 2.78 & 3.34 & \\
\hline $\mathrm{K}_{2} \mathrm{O}$ & 0.68 & 0.55 & 0.60 & 0.61 & 0.62 & 0.65 & 0.19 & 0.21 & 0.18 & 0.52 & \\
\hline $\mathrm{P}_{2} \mathrm{O}_{5}$ & 0.25 & 0.20 & 0.22 & 0.20 & 0.21 & 0.21 & 0.16 & 0.15 & 0.16 & 0.23 & \\
\hline Total & 98.52 & 101.31 & 101.26 & 100.44 & 98.70 & 98.04 & 98.33 & 98.83 & 97.53 & 97.69 & \\
\hline LOI & 1.93 & 1.95 & 1.86 & 2.16 & 1.73 & & & & & & \\
\hline $\mathrm{Ni}$ (ppm) & 15 & 16 & 17 & 12 & 21 & 15 & 85 & 119 & 135 & 35 & \\
\hline $\mathrm{FeO} * / \mathrm{MgO}$ & 1.43 & 1.47 & 1.31 & 1.44 & 1.37 & 1.51 & 1.40 & 1.25 & 1.23 & 1.58 & \\
\hline
\end{tabular}

Note: Analytical ID denotes the laboratory at which the analysis was performed ( $127 \mathrm{SB}=\mathrm{Leg} 127$ shipboard XRF analyses, $128 \mathrm{SB}=\mathrm{Leg} 128$ shipboard XRF analyses, ERI = shorebased XRF analyses at Earthquake Research Institute). Petrographic ID denotes the petrographic classification defined in text (A $=$ aphyric basalt and dolerite, PM $=$ sparsely to moderately plagioclase-phyric basalt and dolerite, $\mathrm{PH}=$ highly plagioclase-phyric basalt and dolerite). ${ }^{*}=$ all iron as divalent. 


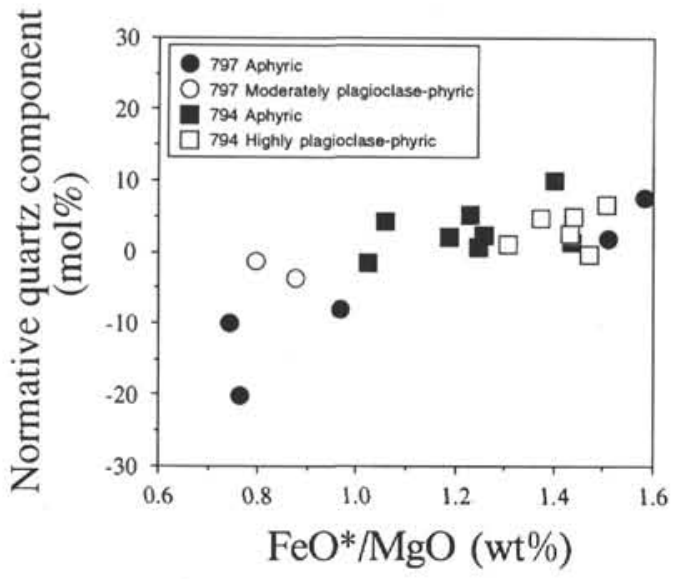

Figure 4 . $\mathrm{FeO} * / \mathrm{MgO}$ vs. normative quartz component variation in the basement basaltic rocks from Sites 794 and 797 . Only the relatively fresh rocks are shown. The amounts of the normative quartz component are calculated by the method of Walker et al. (1979).

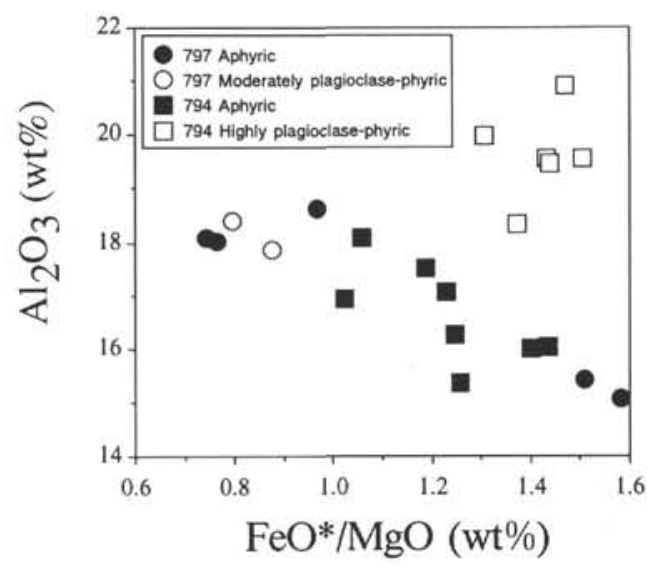

Figure 5. FeO*/MgO vs. $\mathrm{Al}_{2} \mathrm{O}_{3}$ variation in the basement basaltic rocks from Sites 794 and 797. Only the relatively fresh rocks are shown.

the modal amounts of plagioclase phenocrysts seem to increase with increasing $\mathrm{FeO} * / \mathrm{MgO}$ and $\mathrm{Al}_{2} \mathrm{O}_{3}$; and (2) the different concentrations of $\mathrm{Al}_{2} \mathrm{O}_{3}$ between the plagioclase-phyric rocks and the aphyric rocks are not significant at low $\mathrm{FeO} * / \mathrm{MgO}$, but are significant at high $\mathrm{FeO} * / \mathrm{MgO}$. These facts may suggest that the plagioclase-phyric rocks were derived from parents similar to that for the aphyric rocks; in this case, however, crystallized plagioclase was not effectively removed.

\section{Estimation of Primary Magma}

The most important aspect of the compositional features mentioned previously is that, in terms of major-element composition, the aphyric rock with the lowest $\mathrm{FeO} * / \mathrm{MgO}$ (Sample 127-797C-12R-4, $35-37 \mathrm{~cm}$ ) is a good candidate for the parental magma of the basement basaltic rocks from Sites 794 and 797. Sample 127-797C-12R-4, $35-37 \mathrm{~cm}$, also has the highest $\mathrm{MgO}$ (9.91 wt.\%) and $\mathrm{Ni}(165 \mathrm{ppm})$ contents among the selected basement basaltic rocks (Table 1). Primary magma produced in the upper mantle (e.g., Yoder, 1976) should be in equilibrium with mantle peridotite minerals. To estimate the primary magma composition of the basement basaltic rocks from Sites 794 and 797, olivine maximum fractionation (e.g., Sato, 1977; Tatsumi et al., 1983) was backtrack calculated for Sample 127-797C$12 \mathrm{R}-4,35-37 \mathrm{~cm}$. The composition of olivine that is in equilibrium with Sample 127-797C-12R-4, 35-37 cm, was calculated on the basis of $\mathrm{Fe}-\mathrm{Mg}$ and $\mathrm{Ni}-\mathrm{Mg}$ exchange partitioning coefficients between olivine and liquid and then added to the rock in the weight ratio of $1: 99$. This step was repeated until the calculated equilibrium olivine had an $\mathrm{NiO}$ content high enough to match mantle olivine ( $0.4 \mathrm{wt} . \%)$. Assumptions involved in the calculation are as follow: (1) backtrack calculation of olivine maximum fractionation can be applied; (2) $\mathrm{Fe}^{3+} /\left(\mathrm{Fe}^{2+}+\mathrm{Fe}^{3+}\right)$ in magma is kept constant at 0.1 , a value slightly higher than MORBs (e.g., Michael and Chase, 1987), as basalts occurring at backarc basins have slightly higher $\mathrm{Fe}^{3+} /\left(\mathrm{Fe}^{2+}+\mathrm{Fe}^{3+}\right)$ ratio than MORBs (e.g., Hawkins and Melchoir, 1985); (3) $K_{\mathrm{D}}=$ $(\mathrm{Fe} / \mathrm{Mg})_{\mathrm{ol}} /(\mathrm{Fe} / \mathrm{Mg})_{\text {liq }}$ is constant at 0.3 , and the pressure-, temperature-, and composition-dependent variation is not significant (Roeder and Emslie, 1970; Ford et al., 1983; Takahashi and Kushiro, 1983; Ulmer, 1989); (4) $K_{\mathrm{D}}=(\mathrm{Ni} / \mathrm{Mg})_{\mathrm{ol}} /(\mathrm{Ni} / \mathrm{Mg})_{\text {liq }}$ is constant at 2.3 , and the pressure-, temperature-, and composition-dependent variation are not significant (Takahashi, 1978; Kinzler et al., 1990); (5) NiO content in the mantle olivine is $0.4 \mathrm{wt} . \%$, because $\mathrm{NiO}$ contents in mantlederived olivines are rather constant at $0.4 \pm 0.05 \mathrm{wt}$ \% at various localities and geological settings (e.g., Sato, 1977; Elthon, 1989).

When about $10 \mathrm{wt} \%$ of olivine is added to the rock, the $\mathrm{NiO}$ content of calculated olivine appears to be sufficiently high to be mantle olivine. According to this calculation, Sample 127-797C-12R$4,35-37 \mathrm{~cm}$, was produced by about $10 \mathrm{wt}$. \% of olivine fractionation from the primary magma. The calculated mixture yields the primary magma composition, i.e., a picritic high-Al basalt with $\mathrm{MgO}$ at about 14 wt.\% (Table 2), if backtrack calculation of the olivine maximum fractionation is valid.

Table 2. Chemical composition of starting materials.

\begin{tabular}{crrrrrr}
\hline & 1 & \multicolumn{1}{c}{2} & \multicolumn{1}{c}{4} & \multicolumn{1}{c}{5} & 6 \\
\hline $\mathrm{SiO}_{2}$ & 48.54 & 48.80 & 48.27 & 47.87 & 51.59 & 51.04 \\
$\mathrm{TiO}_{2}$ & 0.96 & 1.00 & 0.93 & 0.87 & 1.45 & 1.45 \\
$\mathrm{Al}_{2} \mathrm{O}_{3}$ & 18.10 & 17.79 & 15.72 & 16.39 & 17.06 & 16.89 \\
$\mathrm{FeO}$ & 7.54 & 7.33 & 7.66 & 7.58 & 10.27 & 10.69 \\
$\mathrm{MnO}$ & 0.16 & 0.15 & 0.14 & 0.15 & 0.17 & 0.16 \\
$\mathrm{MgO}$ & 10.13 & 9.21 & 13.79 & 13.96 & 5.32 & 5.20 \\
$\mathrm{CaO}$ & 11.30 & 10.97 & 9.67 & 10.23 & 9.91 & 9.86 \\
$\mathrm{Na} \mathrm{O}_{2} \mathrm{O}$ & 3.10 & 3.03 & 2.59 & 2.81 & 2.98 & 2.82 \\
$\mathrm{~K}_{2} \mathrm{O}$ & 0.05 & 0.09 & 0.09 & 0.05 & 0.74 & 0.80 \\
$\mathrm{P}_{2} \mathrm{O}_{5}$ & 0.12 & n.d. & n.d. & 0.11 & n.d. & 0.29 \\
$\mathrm{FeO} * / \mathrm{MgO}$ & 0.74 & 0.80 & 0.56 & 0.54 & 1.93 & 2.06 \\
\hline
\end{tabular}

Note:

$1=$ Shipboard XRF analysis of Sample $127-797 \mathrm{C}-12 \mathrm{R}-4,35-37 \mathrm{~cm}$.

$2=$ WDS microprobe analysis of the glass of Sample 127-797C-12R-4,

$35-37 \mathrm{~cm}$, fused at $10 \mathrm{kbar}$ and $1260^{\circ} \mathrm{C}$ (above liquidus) (average of 10 analyses).

$3=$ WDS microprobe analysis of the glass of the synthesized estimated primary magma fused at $15 \mathrm{kbar}$ and $1375^{\circ} \mathrm{C}$ (above liquidus) (average of 5 analyses).

4 = estimated primary magma (see text).

$5=$ WDS microprobe analysis of the glass of international standard JB-3

fused at $1 \mathrm{~atm}$ and $1300^{\circ} \mathrm{C}$ (above liquidus) (average of 6 analyses).

$6=$ recommended wet analysis of JB-3 (Ando et al., 1987).

$*=$ all iron as divalent.

n.d. $=$ not detected.

\section{MELTING EXPERIMENTS}

\section{Starting Materials}

A series of melting experiments were conducted for the following two starting materials: (1) Sample 127-797C-12R-4, 35-37 cm, and (2) a synthesized approximation of the estimated primary magma. Chemical compositions of the starting materials are given in Table 2. The powder of Sample 127-797C-12R-4, 35-37 cm, prepared for the shipboard whole-rock XRF analysis, was used in the melting experiments. The sample powder was ground again in an agate mortar for $4 \mathrm{hr}$ under acetone, resulting in a powder with maximum grain size of approximately $20 \mu \mathrm{m}$. The estimated composition of primary 
magma was synthesized by adding olivine $\left(\mathrm{Fo}_{89.5}\right)$ to the powder of Sample $127-797 \mathrm{C}-12 \mathrm{R}-4,35-37 \mathrm{~cm}$, in the weight ratio of $11: 89$. A compositionally uniform olivine crystal from a mantle-derived xenolith from Summit Lake, British Columbia, was used for the addition. To homogenize the mixture, the olivine was coarsely ground first prior to mixing with the sample powder. This mixture was ground in an agate mortar for $4 \mathrm{hr}$ under acetone. Checking composition by analyzing the fused synthetic proved it identical with that of the estimated primary magma (Table 2).

\section{Rationalization of Anhydrous Experiments}

$\mathrm{H}_{2} \mathrm{O}$ is a dominant volatile species in basalt magma. One of the significant compositional features of the basement basaltic rocks from Sites 794 and 797 is low $\mathrm{K}_{2} \mathrm{O}$ contents comparable to that of MORBs (Fig. 6). In particular, the concentration of $\mathrm{K}_{2} \mathrm{O}$ is only $0.2 \mathrm{wt} \%$ or less in the rocks with low $\mathrm{FeO} * / \mathrm{MgO}$. Aoki et al. (1981) suggested that $\mathrm{K}_{2} \mathrm{O}$ and $\mathrm{H}_{2} \mathrm{O}$ contents in basalt magma generally show good positive correlation based on analyses of the basaltic rocks from various geological settings including mid-oceanic ridges. It is widely believed that MORB magmas have very low $\mathrm{H}_{2} \mathrm{O}$ contents (e.g., Michael and Chase, 1987). Therefore, the basement basaltic rocks from Sites 794 and 797 probably contained only a small amount of magmatic $\mathrm{H}_{2} \mathrm{O}$ (below 1 wt. \% according to the $\mathrm{K}_{2} \mathrm{O}-\mathrm{H}_{2} \mathrm{O}$ relation in basalt magma proposed by Aoki et al., 1981). Because such small amounts of $\mathrm{H}_{2} \mathrm{O}$ may not substantially affect the melting-phase relation of a basaltic system (Tatsumi et al., 1983), the melting experiments were performed under anhydrous conditions in this study.

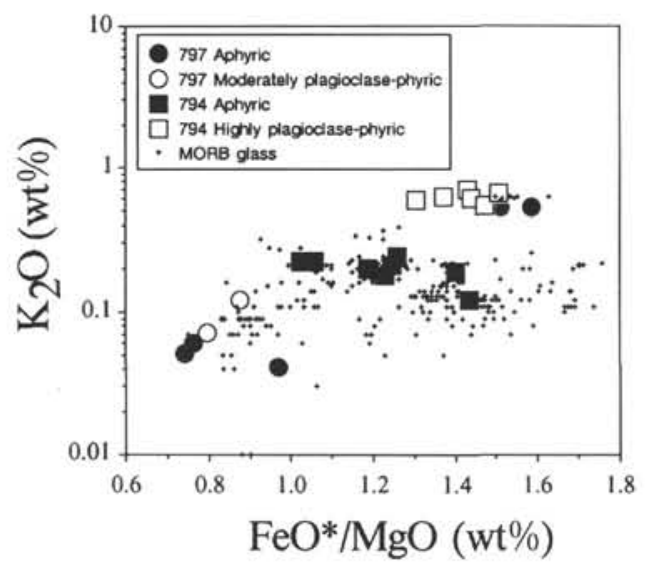

Figure $6 . \mathrm{FeO}^{*} / \mathrm{MgO}$ vs. $\mathrm{K}_{2} \mathrm{O}$ variation in the basement basaltic rocks from Sites 794 and 797. Only the relatively fresh rocks are shown. The variation in MORB glass (Melson et al., 1977; Walker et al., 1979; O'Donnell and Presnall, 1980; Fujii and Bougault, 1983) is also shown. Note that the low $\mathrm{K}_{2} \mathrm{O}$ contents of the rocks from Sites 794 and 797 are comparable to that of MORB glass.

\section{Procedures and Results}

The powders of the starting materials were heated at $1000^{\circ} \mathrm{C}$ under a quartz-fayalite-magnetite (QFM) buffer for $8 \mathrm{hr}$ to break down secondary minerals, and then stored in an oven at $110^{\circ} \mathrm{C}$. The 1 -atm melting experiments were made at oxygen fugacities along QFM buffer in a $\mathrm{CO}_{2} / \mathrm{H}_{2}$ gas-mixture furnace with the Pt-loop method (e.g., Fujii et al., 1978). To minimize Fe exchange between the loop and the sample (e.g., Grove, 1981$)$, a very thin $(0.1 \mathrm{~mm}$ in diameter) wire was employed to suspend relatively large amounts of the sample (60 to $100 \mathrm{mg}$ ). Oxygen fugacities were kept at the values along QFM buffer (Huebner, 1971) by changing the mixing ratio of $\mathrm{CO}_{2}$ and $\mathrm{H}_{2}$. Temperatures were monitored with $\mathrm{Pt} / \mathrm{PtRh} 10$ thermocouples. The experiments were terminated by quenching the run products with water for a few seconds. The high pressure melting experiments were made with a Boyd-England-type solid-media apparatus at the Geological Institute, University of Tokyo. The hot "piston-out" method (Boyd et al., 1967) was employed. In all high pressure runs, graphite capsules were used in the 0.5-in.-diameter furnace assemblages with Pyrex sleeves and graphite heaters. In the run products, the low oxygen fugacity (in the wüstite stability field) was probably achieved as a result of using graphite capsules (Thompson and Kushiro, 1972). Temperatures were measured by $\mathrm{P} / \mathrm{PtRh} 10$ thermocouples. The run products were quenched to temperatures below the solidus in a few seconds. The constituent phases in run products were identified with an optical microscope and a scanning electron microscope (HITACHI S-530T/KEVEX energy-dispersive spectrometer installed) at the Earthquake Research Institute, University of Tokyo. The chemical compositions of constituent phases were determined with a wavelength-dispersive microprobe analyzer (JEOL 733) at the Ocean Research Institute, University of Tokyo, with the data correction method of Bence and Albee (1968). During the analyses, reproducibility was checked by repeatedly analyzing the glass of the international standard basalt (JB-3).

The results of melting experiments are summarized in Table 3 and Figure 7. The representative compositions of the minerals and glass in some run products are given in Table 4.

\section{Sample 127-797C-12R-4, 35-37 cm}

Olivine and plagioclase crystallize nearly simultaneously as the liquidus phases and are followed by $\mathrm{Ca}$-rich clinopyroxene at pressures from $12 \mathrm{kbar}$ to $1 \mathrm{~atm}$ under anhydrous conditions. At pressures above $12 \mathrm{kbar}$, Ca-rich clinopyroxene appears as the liquidus phase instead of olivine and plagioclase. Ca-rich clinopyroxene is followed by plagioclase and olivine with descending temperature. No Ca-poor pyroxene field could be found near liquidus temperatures. The anhydrous melting-phase relation is consistent with that of the compositionally similar olivine tholeiite previously obtained by Thompson (1974).

\section{Synthetic of the Estimated Primary Magma}

At pressures below $14 \mathrm{kbar}$, olivine is the liquidus phase. Olivine is replaced by orthopyroxene at pressures above $14 \mathrm{kbar}$. Ca-rich clinopyroxene is also observed in the run products at the near-liquidus temperatures above $14 \mathrm{kbar}$. Such $\mathrm{Ca}$-rich clinopyroxene does not occur as a discrete crystal, but as an overgrown crystal on the liquidus orthopyroxene, suggesting that the $\mathrm{Ca}$-rich clinopyroxene is a rapidly grown metastable crystal. Discrete Ca-rich clinopyroxene follows the liquidus orthopyroxene with descending temperature. According to the present results, olivine and orthopyroxene crystallize nearly simultaneously as the liquidus phases at approximately $14 \mathrm{kbar}$ and $1330^{\circ} \mathrm{C}$ under anhydrous conditions, suggesting that the estimated primary magma composition can coexist with a harzburgitic mineral assemblage at such conditions.

\section{Differentiation Processes of Basement Basaltic Rocks}

Sample 127-797C-12R-4, 35-37 cm has Ca-rich clinopyroxene as the liquidus phase together with olivine and plagioclase at about 12 kbar under anhydrous conditions (Fig. 7). Chemical compositions of phases coexisting at temperatures just below the liquidus at about 12 kbar were determined (Table 4 and Fig. 8). The residual liquid at about $12 \mathrm{kbar}$ is depleted in normative quartz component relative to the starting composition (Fig. 8). This topography of the anhydrous melting-phase relation is consistent with those previously suggested by several investigations at $8 \mathrm{kbar}$ for olivine tholeiitic starting compositions (Fig. 8; Baker and Eggler, 1987; Grove et al., 1990). Figure 8 suggests that the quartz component-enrichment in the differentiated aphyric rocks cored at Sites 794 and 797 (Fig. 4) could not be produced by crystallization differentiation of compositional equivalents of Sample 127-797C-12R-4, 35-37 cm, at elevated pres- 
Table 3. Results of melting experiments.

\begin{tabular}{|c|c|c|c|c|c|}
\hline Run & $\begin{array}{l}\text { Starting Material } \\
\text { Sample 127-797C- }\end{array}$ & $\begin{array}{l}\text { Pressure } \\
\text { (kbar) }\end{array}$ & $\begin{array}{c}\text { Temperature } \\
\left({ }^{\circ} \mathrm{C}\right)\end{array}$ & $\begin{array}{l}\text { Duration } \\
\text { (min) }\end{array}$ & Run Product \\
\hline 2008 & $12 \mathrm{R}-4,35-37$ & 10 & 1260 & 120 & glass \\
\hline 2009 & $12 R-4,35-37$ & 10 & 1240 & 120 & glass + olivine + plagioclase \\
\hline 2010 & $12 \mathrm{R}-4,35-37$ & 10 & 1220 & 120 & glass + olivine + plagioclase + Ca-rich clinopyroxene \\
\hline 2011 & $12 \mathrm{R}-4,35-37$ & 11.5 & 1240 & 120 & glass + olivine + plagioclase + Ca-rich clinopyroxene \\
\hline 2012 & $12 \mathrm{R}-4,35-37$ & 11.5 & 1220 & 120 & glass + olivine + plagioclase + Ca-rich clinopyroxene \\
\hline 2013 & $12 R-4,35-37$ & 12 & 1250 & 300 & glass + olivine + plagioclase \\
\hline 2017 & $12 \mathrm{R}-4,35-37$ & 12.5 & 1250 & 165 & glass + olivine + plagioclase + Ca-rich clinopyroxene \\
\hline 2019 & $12 R-4,35-37$ & 13 & 1300 & 120 & glass \\
\hline 2020 & $12 R-4,35-37$ & 13 & 1280 & 105 & glass \\
\hline 2007 & $12 R-4,35-37$ & 13 & 1280 & 110 & glass + Ca-rich clinopyroxene \\
\hline 2018 & $12 \mathrm{R}-4,35-37$ & 13 & 1270 & 130 & glass + plagioclase + Ca-rich clinopyroxene \\
\hline 2016 & $12 \mathrm{R}-4,35-37$ & 13 & 1260 & 210 & glass + olivine + plagioclase + Ca-rich clinopyroxene \\
\hline 2006 & $12 R-4,35-37$ & 13 & 1260 & 45 & glass + olivine + plagioclase + Ca-rich clinopyroxene \\
\hline 2015 & $12 \mathrm{R}-4,35-37$ & 13 & 1250 & 210 & glass + olivine + plagioclase + Ca-rich clinopyroxene \\
\hline 2023 & $12 R-4,35-37$ & 13 & 1220 & 96 & glass + olivine + plagioclase + Ca-rich clinopyroxene \\
\hline 2022 & $12 \mathrm{R}-4,35-37$ & 15 & 1320 & 70 & glass \\
\hline 2005 & $12 R-4,35-37$ & 15 & 1300 & 90 & glass $+\mathrm{Ca}$-rich clinopyroxene \\
\hline 2021 & $12 \mathrm{R}-4,35-37$ & 15 & 1280 & 120 & glass + Ca-rich clinopyroxene + plagioclase (rare) \\
\hline 2024 & $12 \mathrm{R}-4,35-37$ & 15 & 1220 & 140 & glass + olivine + plagioclase + Ca-rich clinopyroxene \\
\hline AP-7 & $12 R-4,35-37$ & $1 \mathrm{~atm}$ & 1245 & $10 \mathrm{hr}$ & glass \\
\hline AP-3 & $12 R-4,35-37$ & $1 \mathrm{~atm}$ & 1229 & $19 \mathrm{hr}$ & glass + olivine + plagioclase \\
\hline AP-6 & $12 \mathrm{R}-4,35-37$ & $1 \mathrm{~atm}$ & 1214 & $16 \mathrm{hr}$ & glass + olivine + plagioclase \\
\hline AP-1 & $12 R-4,35-37$ & $1 \mathrm{~atm}$ & 1200 & $36 \mathrm{hr}$ & glass + olivine + plagioclase \\
\hline AP-4 & $12 R-4,35-37$ & $1 \mathrm{~atm}$ & 1183 & $51 \mathrm{hr}$ & glass + olivine + plagioclase \\
\hline AP-5 & $12 \mathrm{R}-4,35-37$ & $1 \mathrm{~atm}$ & 1166 & $56 \mathrm{hr}$ & glass + olivine + plagioclase + Ca-rich clinopyroxene \\
\hline 2110 & Synthetic primary magma & 11 & 1300 & 100 & glass + olivine \\
\hline 2115 & Synthetic primary magma & 11 & 1250 & 120 & glass + olivine \\
\hline 2121 & Synthetic primary magma & 13 & 1355 & 100 & glass \\
\hline 2113 & Synthetic primary magma & 13.5 & 1280 & 120 & glass + olivine + orthopyroxene + Ca-rich clinopyroxene + plagioclase \\
\hline 2118 & Synthetic primary magma & 14 & 1330 & 100 & glass + olivine + orthopyroxene + Ca-rich clinopyroxene* \\
\hline 2112 & Synthetic primary magma & 14 & 1310 & 120 & glass + olivine + orthopyroxene + Ca-rich clinopyroxene* \\
\hline 2105 & Synthetic primary magma & 15 & 1375 & 120 & glass \\
\hline 2108 & Synthetic primary magma & 15 & 1300 & 120 & glass + orthopyroxene + Ca-rich clinopyroxene + plagioclase (rare) \\
\hline 2109 & Synthetic primary magma & 17 & 1325 & 130 & glass + orthopyroxene + Ca-rich clinopyroxene + plagioclase (rare) \\
\hline 2107 & Synthetic primary magma & 18 & 1375 & 120 & glass + orthopyroxene + Ca-rich clinopyroxene* \\
\hline 2103 & Synthetic primary magma & 20 & 1450 & 100 & glass \\
\hline 2104 & Synthetic primary magma & 20 & 1422 & 100 & glass + orthopyroxene + Ca-rich clinopyroxene (rare) \\
\hline 2101 & Synthetic primary magma & 20 & 1400 & 110 & glass + orthopyroxene + Ca-rich clinopyroxene* \\
\hline
\end{tabular}

Note:

* = rapidly grown metastable Ca-rich clinopyroxene (see text).
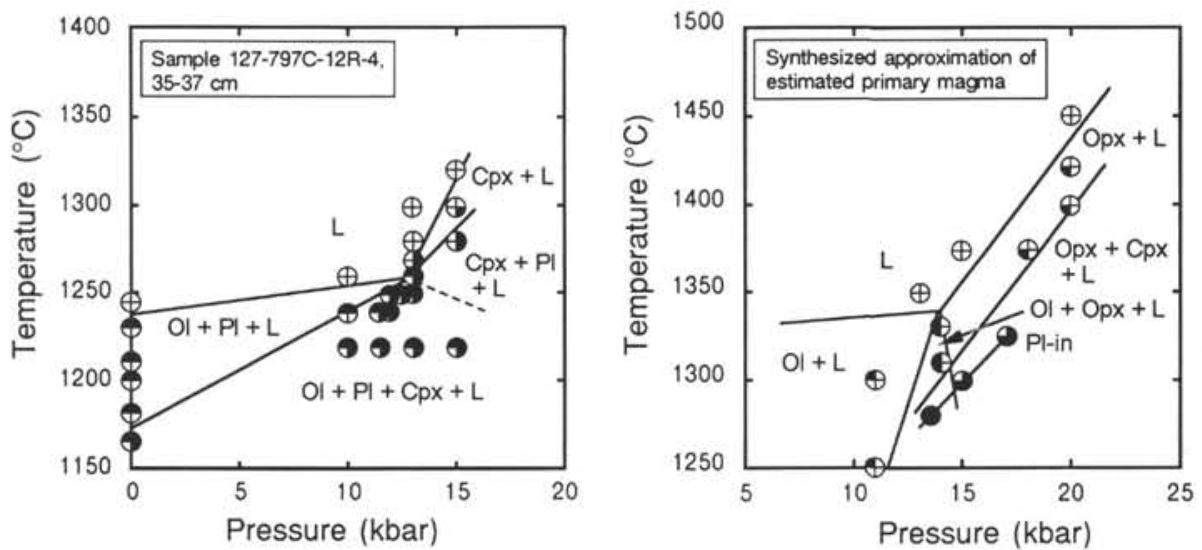

Figure 7. Anhydrous melting-phase relations for the two starting materials (see text). Abbreviations are the following: $\mathrm{L}=$ quenched liquid (glass), $\mathrm{Ol}=$ olivine, $\mathrm{Pl}=$ plagioclase, $\mathrm{Cpx}=\mathrm{Ca}$-rich clinopyroxene, and Opx $=$ orthopyroxene. 
Table 4. Representative analyses of constituent phases in the run products at high pressures.

\begin{tabular}{|c|c|c|c|c|c|c|c|}
\hline & 1 & 2 & 3 & 4 & 5 & 6 & 7 \\
\hline $\mathrm{SiO}_{2}$ & 47.18 & 39.12 & 51.95 & 49.81 & 48.11 & 39.32 & 55.77 \\
\hline $\mathrm{TiO}_{2}$ & 1.39 & n.d. & n.d. & 0.61 & 1.20 & n.d. & 0.14 \\
\hline $\mathrm{Al}_{2} \overline{\mathrm{O}}_{3}$ & 17.83 & 0.11 & 28.56 & 8.77 & 18.87 & 0.13 & 3.34 \\
\hline $\mathrm{FeO} *$ & 9.78 & 15.32 & 1.48 & 7.29 & 8.00 & 12.29 & 6.63 \\
\hline $\mathrm{MnO}$ & 0.11 & 0.17 & n.d. & 0.21 & 0.18 & 0.17 & n.d. \\
\hline $\mathrm{MgO}$ & 7.83 & 42.95 & 0.77 & 18.15 & 9.03 & 45.82 & 31.09 \\
\hline $\mathrm{CaO}$ & 10.02 & 0.35 & 14.16 & 13.95 & 10.06 & 0.30 & 2.32 \\
\hline $\mathrm{Na}_{2} \mathrm{O}$ & 3.78 & n.d. & 3.89 & 0.57 & 3.61 & n.d. & 0.12 \\
\hline $\mathrm{K}_{2} \mathrm{O}$ & 0.10 & n.d. & n.d. & n.d. & 0.10 & n.d. & n.d. \\
\hline Total & 98.02 & & 100.81 & 99.36 & 99.16 & 98.03 & 99.41 \\
\hline number of oxygens & & 4 & 8 & 6 & & 4 & 6 \\
\hline $\mathrm{Si}$ & & 1.004 & 2.363 & 1.813 & & 0.996 & 1.943 \\
\hline $\mathrm{Ti}$ & & n.d. & n.d. & 0.017 & & n.d. & 0.004 \\
\hline $\mathrm{Al}$ & & 0.003 & 1.531 & 0.376 & & 0.004 & 0.137 \\
\hline $\mathrm{Fe}^{*}$ & & 0.329 & 0.056 & 0.222 & & 0.260 & 0.193 \\
\hline $\mathrm{Mn}$ & & 0.004 & n.d. & 0.006 & & 0.004 & n.d. \\
\hline $\mathrm{Mg}$ & & 1.643 & 0.052 & 0.985 & & 1.730 & 1.614 \\
\hline $\mathrm{Ca}$ & & 0.010 & 0.690 & 0.544 & & 0.008 & 0.087 \\
\hline $\mathrm{Na}$ & & n.d. & 0.343 & 0.040 & & n.d. & 0.008 \\
\hline K & & n.d. & n.d. & n.d. & & n.d. & n.d. \\
\hline Total & & 2.993 & 5.035 & 4.003 & & 3.002 & 3.986 \\
\hline $\mathrm{Mg} /\left(\mathrm{Mg}+\mathrm{Fe}^{*}\right)$ & 0.588 & 0.833 & & 0.816 & 0.668 & 0.869 & 0.893 \\
\hline Wo & & & & 31.08 & & & 4.57 \\
\hline En & & & & 56.24 & & & 85.23 \\
\hline Fs & & & & 12.68 & & & 10.20 \\
\hline
\end{tabular}

Note:

$I=$ glass (run 2017: Sample 127-797C-12R-4. 35-37 cm).

2 = olivine (run 2017: Sample 127-797C-12R-4, 35-37 cm)

3 = plagioclase (run 2017: Sample 127-797C-12R-4. 35-37 cm).

4 = Ca-rich clinopyroxene (run 2017: Sample 127-797C-12R-4. $35-37 \mathrm{~cm}$ ).

5 = glass (run 2118: Synthesized primary magma).

$6=$ olivine (run 2118: Synthesized primary magma).

$7=$ orthopyroxene (run 2118: Synthesized primary magma).

* $=$ all iron as divalent.

sure because the residual liquids at such pressure would be driven toward quartz component-deficient compositions. Alternatively, the quartz component-enrichment in the differentiated aphyric rocks might be produced by crystallization differentiation of compositional equivalents of Sample 127-797C-12R-4, 35-37 cm, at relatively low pressure where olivine and plagioclase fractionation was followed by $\mathrm{Ca}$-rich clinopyroxene fractionation (Fig. 7).

The atmospheric density of Sample 127-797C-12R-4, 35-37 cm, near the liquidus temperature $\left(1250^{\circ} \mathrm{C}\right.$; Fig. 7) is estimated at 2.66 $\mathrm{g} / \mathrm{cm}^{3}$ using Lange and Carmichael's (1987) partial molar volume data and assuming $\mathrm{Fe}^{3+} /\left(\mathrm{Fe}^{2+}+\mathrm{Fe}^{3+}\right)=0.1$. This value is only slightly lower than that of calcic plagioclase (approximately $2.7 \mathrm{~g} / \mathrm{cm}^{3}$; e.g., Gill, 1981). It means that the densities of Sample 127-797C-12R-4, 35-37 $\mathrm{cm}$, and the differentiated liquids must be comparable to that of calcic plagioclase at some depth, but still at relatively low pressure, under anhydrous conditions because density of basaltic liquid rapidly increases with increasing pressure, descending temperature, and increasing $\mathrm{FeO} * / \mathrm{MgO}$ ratio (e.g., Kushiro, 1982; Lange and Carmichael, 1987). Therefore, it is possible that, throughout crystallization differentiation of compositional equivalents of Sample 127-797C-12R-4, 35-37 cm, at relatively low pressure, the liquidus plagioclase was not effectively removed and was retained in the successive residual liquids to form the plagioclase-phyric rocks. This scenario is consistent with the compositional feature of the plagioclase-phyric rocks mentioned previously (Fig. 5).

In estimating the primary magma composition from Sample 127$797 \mathrm{C}-12 \mathrm{R}-4,35-37 \mathrm{~cm}$, the only olivine fractionation was assumed and the role of other minerals was not addressed. In reality, Sample $127-797 \mathrm{C}-12 \mathrm{R}-4,35-37 \mathrm{~cm}$, is saturated in plagioclase together with olivine at the conditions likely for the successive differentiation (Fig. 7). This feature may preclude applying the backtrack of olivine maximum fractionation to estimate the primary magma composition.

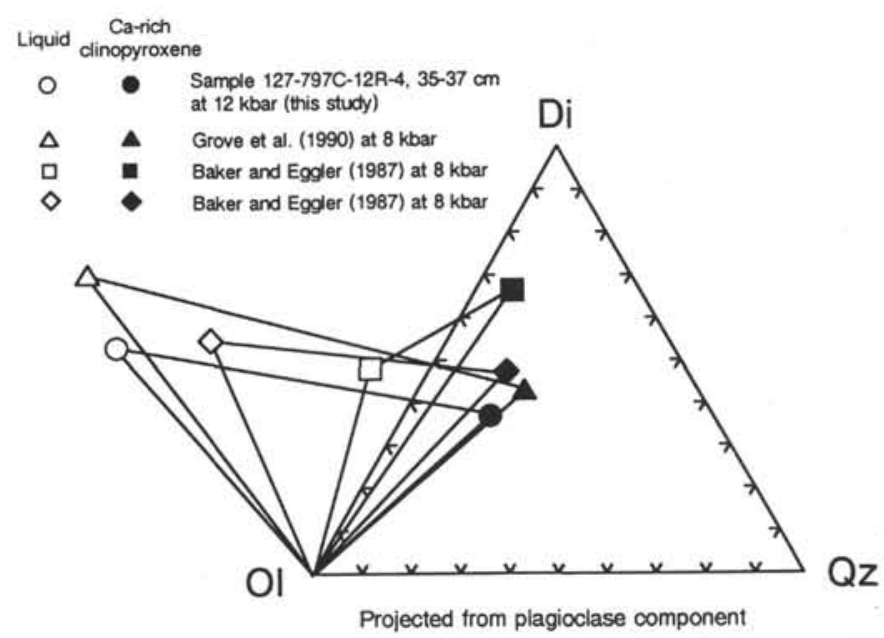

Figure 8. Melting-phase relation of Sample $127-797 \mathrm{C}-12 \mathrm{R}-4,35-37 \mathrm{~cm}$, on the plagioclase-saturated surface at about $12 \mathrm{kbar}$. Previous measurements of olivine tholeiitic basalts at about $8 \mathrm{kbar}$ are also shown. Coexisting phases are connected by tie-lines. The projection method is from Walker et al. (1979).

As mentioned above, however, the plagioclase-phyric rocks can be explained from compositional equivalents of Sample 127-797C-12R$4,35-37 \mathrm{~cm}$, by retention of crystallized plagioclase. In this case the aphyric nature of Sample 127-797C-12R-4, 35-37 cm, suggests that Sample $127-797 \mathrm{C}-12 \mathrm{R}-4,35-37 \mathrm{~cm}$, has been saturated just in plagioclase. This allows us to assume that Sample 127-797C-12R-4, $35-37 \mathrm{~cm}$, is free from significant prior plagioclase fractionation, so the estimated primary magma composition is justified.

\section{Primary Magma Production}

Sample $127-797 \mathrm{C}-12 \mathrm{R}-4,35-37 \mathrm{~cm}$, has no Ca-poor pyroxene field at near-liquidus temperatures whereas both $\mathrm{Ca}$-rich clinopyroxene and olivine occur as the liquidus phase at about $12 \mathrm{kbar}$ under anhydrous conditions (Fig. 7). Ca-rich clinopyroxene is the first phase to disappear from peridotitic mineral assemblage with an increasing extent of partial melting (e.g., Mysen and Kushiro, 1977; Jaques and Green, 1980; Falloon et al., 1988). The obtained high-pressure melting-phase relation, therefore, suggests that Sample 127-797C-12R-4, $35-37 \mathrm{~cm}$, can not represent a primary magma produced by partial melting of mantle peridotite. On the other hand, the synthesized approximation of the estimated primary magma does not have Ca-rich clinopyroxene, but has olivine and orthopyroxene as the liquidus phases at about 14 kbar under anhydrous conditions (Fig. 7). This suggests that the estimated primary magma composition can be produced by partial melting of mantle peridotite at such conditions, leaving harzburgitic mantle as a residue. Accordingly, the primary magma associated with the regional rifting of the area might be produced at about $14 \mathrm{kbar}$ (approximately $40-50 \mathrm{~km}$ below surface). The production depth is not distinct from that beneath the mid-oceanic ridge (e.g., Fujii and Bougault, 1983), confirming the prediction based on the thermal structure beneath the backarc side of Miocene northeastern Japan (Nohda et al., 1988; Tatsumi et al., 1989). This kind of shallow production of primary magma is likely for a situation in which regional stretching and probable detachment of the overlying rigid continental lithosphere occur.

\section{ACKNOWLEDGMENTS}

We acknowledge Kensaku Tamaki for his principal role in obtaining the samples studied here. Valuable suggestions and criticism given by Don Elthon, Martin Fisk, Susumu Nohda, and Yoshiyuki Tatsumi improved an early version of the manuscript. One of the authors (S.Y.) 
thanks his shipboard colleagues "Igpets" during Ocean Drilling Program Leg 127 (Jamie Allan, Kathy Stewart, and Peter Thy) for their enjoyable collaboration.

\section{REFERENCES}

Ando, A., Mita, N., and Terashima, S., 1987. 1986 values for fifteen GSJ rock reference samples, "igneous rock series." Geostand. Newsl., 11:159-166.

Aoki, K., Ishikawa, K., and Kanisawa, S., 1981. Fluorine geochemistry of basaltic rocks from continental and oceanic regions and petrogenetic application. Contrib. Mineral. Petrol., 76:53-59.

Aramaki, S., 1987. Geological background of the lethal gas burst from Lake Nyos, Cameroon, August 1986. Bull. Volcanol. Soc. Jpn., 32:57-72. (Japanese with English abstract)

Baker, D. R., and Eggler, D. H., 1987. Compositions of anhydrous and hydrous melts coexisting with plagioclase, augite, and olivine or low-Ca pyroxene from $1 \mathrm{~atm}$ to $8 \mathrm{kbar}$ application to the Aleutian volcanic center of Atka. Am. Mineral., 72:12-28.

Bence, A. E., and Albee, A. L., 1968. Empirical correction factors for the electron microanalysis of silicates and oxides. J. Geol., 76:382-403.

Boyd, F. R., Bell, P. M., England, J. L., and Gilbert, M. C., 1967. Pressure measurement in single-stage apparatus. Carnegie Inst. Washington Year Book, 65:410-414.

Celaya, M., and McCabe, R., 1987. Kinematic opening of the Sea of Japan and the bending of the Japanese Island. Geology, 15:53-57.

Elthon, D., 1989. Pressure of origin of primary mid-oceanic ridge basalts. In Saunders, A. D., and Norry, M. J. (Eds.), Magmatism in the Ocean Basins. Geol. Soc. Spec. Publ. London, 42:125-136.

Falloon, T. J., Green, D. H., Hatton, C. J., and Harris, K. L., 1988. Anhydrous partial melting of a fertile and depleted peridotite from 2 to $30 \mathrm{~kb}$ and application to basalt petrogenesis. J. Petrol., 29:1257-1282.

Ford, C. E., Russel, D. G., Graven, J. A., and Fisk, M. R., 1983. Olivine liquid equilibria; temperature, pressure, and composition dependence of the crystal/liquid cation partition coefficients for $\mathrm{Mg}, \mathrm{Fe}^{2+}, \mathrm{Ca}$, and $\mathrm{Mn}$. J. Petrol., 24:256-265.

Fujii, T., Kushiro, I., and Hamuro, K., 1978. Melting relation and viscosity of an abyssal olivine tholeiite. In Melson, W. G., Rabinowitz, P. D., et al., Init. Repts. DSDP, 45: Washington (U.S. Govt. Printing Office), 513-517.

Fujii, T., and Bougault, H., 1983. Melting relations of a magnesian abyssal tholeiite and the origin of MORBs. Earth Planet. Sci. Lett., 62:283-295.

Gill, J. B., 1981. Orogenic Andesites and Plate Tectonics: Berlin (Springer-Verlag).

Grove, T. L., 1981. Use of FePt alloys to eliminate the iron loss problem in 1 atmosphere gas mixing experiments: theoretical and practical considerations. Contrib. Mineral. Petrol., 78:298-304.

Grove, T. L., Kinzler, R. J., and Bryan, W. B., 1990. Natural and experimental phase relations of lavas from Seocki volcano. In Detrick, R., Honnorez, J., Bryan, W. B., and Juteau, T., et al., Proc. ODP, Sci. Results, 106/109: College Station, TX (Ocean Drilling Program), 9-18.

Hawkins, J. W., and Melchior, J. T., 1985. Petrology of Mariana Trough and Lau Basin basalts. J. Geophys. Res., 90:11431-11468.

Hirata, N., Tokuyama, H., and Chung, T. W., 1989. An anomalously thick layering of the crust of the Yamato basin, southeastern Sea of Japan: the final stage of back-arc spreading. Tectonophysics, 165:303-314.

Huebner, J. S., 1971. Buffering techniques for hydrostatic systems at elevated pressures. In Ulmer, G. C. (Ed.), Research Techniques for High Pressure and High Temperature.: Berlin (Springer-Verlag), 123-177.

Ingle, J. C., Jr., Suyehiro, K., and von Breymann, M. T., et al., 1990. Proc. ODP, Init. Repts., 128: College Station, TX (Ocean Drilling Program).

Jaques, A. L., and Green, D. H., 1980. Anhydrous melting of peridotite at $0-15 \mathrm{~kb}$ pressure and the genesis of tholeiitic basalts. Contrib. Mineral. Petrol., 73:287-310

Kinzler, R. J., Grove, T. L., and Recca, S. I., 1990. An experimental study on the effect of temperature and melt composition on the partitioning of nickel between olivine and silicate melt. Geochim. Cosmochim. Acta, 54:1255-1265.

Kuno, H., 1960. High-alumina basalt. J. Petrol., 1:121-145.

Kushiro, I., 1982. Density of tholeiite and alkali basalt magmas at high pressures. Carnegie Inst. Washington Year Book, 81:305-309.

Lange, R. A., and Carmichael, I.S.E., 1987. Densities of $\mathrm{Na}_{2} \mathrm{O}-\mathrm{K}_{2} \mathrm{O}-\mathrm{MgO}-$ $\mathrm{FeO}-\mathrm{Fe}_{2} \mathrm{O}_{3}-\mathrm{Al}_{2} \mathrm{O}_{3}-\mathrm{TiO}_{2}-\mathrm{SiO}_{2}$ liquids: new measurements and derived partial molar properties. Geochim. Cosmochim. Acta, 51:2931-2946.
Melson, W. G., Vallier, T. L., Wright, T. L., Byerly, G. R., and Nelen, J. A., 1977. A catalog of major element chemistry of abyssal volcanic glasses. Smithsonian Contrib. Earth Sci., 19:31-60.

Menzies, M., and Seyfried, W. E., 1979. Basalt-seawater interaction: trace element and strontium isotopic variations in experimentally altered glassy basalt. Earth Planet. Sci. Lett., 44:463-472.

Michael, P. J., and Chase, R. L., 1987. The influence of primary magma composition, $\mathrm{H}_{2} \mathrm{O}$ and pressure on Mid-Ocean Ridge basalt differentiation. Contrib. Mineral. Petrol., 96:245-263.

Mysen, B. O., and Kushiro, I., 1977. Compositional variations of coexisting phases with degree of melting of peridotite in the upper mantle. Am. Mineral., 62:843-865.

Nohda, S., Tatsumi, Y., Otofuji, Y., Matsuda, T., and Ishizaka, K., 1988. Asthenospheric injection and back arc opening: isotopic evidence from NE Japan. Chemical. Geol., 68:317-327.

O'Donnell, T. H., and Presnall, D. C., 1980. Chemical variations of the glass and mineral phases in basalts dredged from $25-30^{\circ} \mathrm{N}$ along the mid-Atlantic ridge. Am. J. Sci., 280A:845-868.

Otofuji, Y., Hayashida, A., and Torii, M., 1985. When was the Japan Sea opened? Paleomagnetic evidence from southwest Japan. In Nasu, N., Kobayashi, K., Uyeda, S., Kushiro, I., and Kagami, H. (Eds.), Formation of Active Ocean Margins: Tokyo (Terra Publ.), 551-556.

Roeder, P. L., and Emslie, R. F., 1970. Olivine-liquid equilibrium. Contrib. Mineral. Petrol., 29:275-289.

Sato, H., 1977. Nickel content of basaltic magmas: identification of primary magmas and a measure of the degree of olivine fractionation. Lithos, 10:113-120.

Seyfried, W. E., and Mottl, M. J., 1982. Hydrothermal alteration of basalt by seawater under seawater-dominated conditions. Geochim. Cosmochim. Acta, 46:985-1002.

Tada, R., 1990. Evolution of sedimentary environment in Japan Sea since the initiation of Yamato Basin [paper presented at the Geol. Soc. Japan meeting, Toyama]. (in Japanese)

Takahashi, E., 1978. Partitioning of $\mathrm{Ni}^{2+}, \mathrm{Co}^{2+}, \mathrm{Fe}^{2+}, \mathrm{Mn}^{2+}$, and $\mathrm{Mg}^{2+}$ between olivine and silicate melts: compositional dependence of partition coefficient. Geochim. Cosmochim. Acta, 42:1829-1844.

Takahashi, E., and Kushiro, L., 1983. Melting of dry peridotite at high pressure and basalt magma genesis. Am. Mineral., 68:859-879.

Tamaki, K., 1988. Geological structure of the Japan Sea and its tectonic implications. Chishitsu Chosasho Geppo, 39:269-365.

Tamaki, K., Pisciotto, K., Allan, J., et al., 1990. Proc. ODP, Init. Repts., 127: College Station, TX (Ocean Drilling Program).

Tatsumi, Y., Otofuji, Y., Matsuda, T., and Nohda, S., 1989. Opening of the Sea of Japan back-arc basin by asthenospheric injection. Tectonophysics, 166:317-329.

Tatsumi, Y., Sakuyama, M., Fukuyama, H., and Kushiro, I., 1983. Generation of arc basalt magmas and thermal structure of the mantle wedge in subduction zones. J. Geophys. Res., 88:5815-5825.

Thompson, R. N., 1974. Primary basalts and magma genesis. I. Skye, NorthWest Scotland. Contrib. Mineral. Petrol., 45:317-341.

Thompson, R. N., and Kushiro, I., 1972. The oxygen fugacity within graphite capsules in piston cylinder apparatus at high pressures. Carnegie Inst. Washington Year Book, 71:615-616.

Tokuyama, H., Suyemasu, M., Tamaki, K., Nishiyama, E., Kuramoto, S. Suyehiro, K., Kinoshita, H., and Taira, A., 1987. Report on DELP 1985 Cruise in the Japan Sea. Part III: Seismic reflection studies in the Yamato basin and the Yamato rise area. Bull. Earthq. Res. Inst. Univ. Tokyo, $62: 367-390$.

Ulmer, $\mathrm{P} ., 1989$. The dependence of the $\mathrm{Fe}^{2+}-\mathrm{Mg}$ cation-partitioning between olivine and basaltic liquid on pressure, temperature, and composition. An experimental study to 30 kbars. Contrib. Mineral. Petrol., 101:261-273.

Walker, D., Shibata, T., and DeLong, S. E., 1979. Abyssal tholeiites from the Oceanographer fracture zone. II. Phase equilibria and mixing. Contrib. Mineral. Petrol., 70:111-125.

Yoder, H. S., Jr., 1976. Generation of Basaltic Magma: Washington (Nat. Acad. Sci.), 12-43.

Date of initial receipt: 19 March 1991

Date of acceptance: 16 October 1991

Ms 127/128B-206 